\title{
Phytoremediation of Heavy Metal Contaminated Water Using Potential Caspian Sea Wetland Plant: Nymphaeaceae
}

\author{
Parisa Ziarati $^{1 *}$, Jinous Asgarpanah ${ }^{2}$ and Fatemehsadat MirMohammad Makki ${ }^{3}$ \\ ${ }^{1}$ Department of Medicinal Chemistry, Faculty of Pharmacy ,Pharmaceutical Sciences Branch, \\ Islamic Azad University (IAUPS), Tehran, Iran. \\ ${ }^{2}$ Department of Pharmacognosy, Faculty of Pharmacy, Pharmaceutical Sciences Branch, \\ Islamic Azad University, Tehran, Iran (IAUPS). \\ ${ }^{3}$ Young Researchers Club, Pharmaceutical Sciences Branch, \\ Islamic Azad University (IAUPS), Tehran, Iran.
}

DOI: http://dx.doi.org/10.13005/bbra/1925

(Received: 27 September 2015; accepted: 19 November 2015)

\begin{abstract}
Aquatic plant communities are good candidates for treating groundwater contamination systems due to large surface area, ease of culture and high organic uptake potential. We investigated the potential of the Nymphaeaceae high-biomass Ni hyperaccumulator to phytoextract $\mathrm{Cr}$ and $\mathrm{Ni}$ from artificial metalliferous media. Nymphaeaceae was collected from area located in Anzali lagoon (Iran) where is full of Nymphaeaceae's. Plants were treated with 100-600 ì of Chromium and Nickel solutions for 10 days. Cr was introduced independently at two speciations as Cr (III) and $\mathrm{Cr}$ (VI), which are known for their diverse physicochemical properties and different influence on living organisms. None-parametric Kruskal-Wallis/Mann-Whitney $U$ tests were applied to compare differences between objects. Non-parametric multiple comparison test (Dunn's test) was performed to determine statistical significance of results at $\alpha=0.05$. Results indicate significant differences in $\mathrm{Cr}$ distribution in both groups of Cr-treated plants and in the plants exposed to $\mathrm{Cr}$ (III) and $\mathrm{Cr}$ (VI). The amount of $\mathrm{Cr}$ deposited in leaves in both Cr-treated plants differed significantly. As expected the heavy metals uptake rate by this plant is significantly affected by number of plant cultivated as for Nickel uptake $(p<0.03)$ while for chrome the $p$-value was less than 0.01 . The results of this research concluded that Nymphaeaceae in the contaminated water had suitable ability for phytoremediation by method and transmitting more Chrome and Nickel in pH $\leq 7$ after 10 days of growth of Nymphaeaceae spices. Plant accumulation of all metals from single-element substrates indicate that the bioaccumulation coefficient increases as total metal concentrations increase.
\end{abstract}

Key words: Nymphaeaceae; Phytoremediation ;Aquatic plant; Chrome ;Nickel; Caspian Sea.

Water pollution is a major global problem and it is leading worldwide cause of deaths and diseases. Pollution of the biosphere with toxic metals has accelerated dramatically since the beginning of the Industrial Revolution ${ }^{1-2}$. Wetland

\footnotetext{
* To whom all correspondence should be addressed. Tel: +98-21-22600037; Fax: +98-21-22633986; E-mail: ziarati.p@iaups.ac.ir
}

is a water environment which has considerable scientific, economical, and, social values. They are the habitats of various organisms contributing to the gene cache of microbes, plants and animals on the earth. However nowadays the pollution and degradation of the wetlands are dramatically increasing ${ }^{3}$. Marine animals can accumulate metals through sea water, suspended particles, sediments and food chains. Permanent contaminants such 
as metals may be transferred to higher levels in the food chain through environmental expansion. The levels of these contaminants, due to environmental socialization of species are generally much higher in marine physico than the surroundings ${ }^{4}$.

The vast industrial waste materials and sewages from a lot factories and different chemical fertilizers and pesticides in Tehran have caused contamination of soils ${ }^{5}$. The soil and water of other cities especially in the north of Iran has been already contaminated. Gilan Province, owing to its rich natural resources, is one of the most populated provinces in $\operatorname{Iran}^{6}$. Irrigated agriculture is one of the most well-known causes of groundwater contamination throughout the Gilan state (south Caspian Area) in the north of Iran. According to the provincial statistics in 1998, Rasht City 1.4 million $\mathrm{m}^{3}$ untreated sewage into the river which is attributed to the increasing urban development ${ }^{7}$. There are more than 30 main polluted factories in Gilan $^{8}$. Among these industries, Wood and Paper Company in Talesh, Wood Fiber Company in Hassan Rood, Iran Poplin textile, Gilan Carpet, Pars Khazar house ware, Zam-Zam soft drink, and several food industries in Rasht are important to mention. The lack of proper wastewater treatment plant in some of these companies will add pollution to the rivers that will end to the Wetland. Department of Environment (DOE) has established standards and regulations for discharging pollution to the environment ${ }^{9-10}$. Although, lots of effort has been applied so far to implement the DOE's laws and regulations in all activities of I. R. Iran including industries, hospitals and trade centers, but lots of works need to be done to secure the job. It has been shown that the most polluting sources are from industries.

The concentrations of pollutants in textile wastewaters vary according to the wastewater management practices and their dilution after production. Textile dyes are one of the most prevalent types of chemicals in use today. Around 10000 different dyes with an annual production of more than $7 \times 105$ metric tons worldwide are commercially available. Heavy metals are the most dangerous type of chemical pollutants since they cause serious health hazard. In India, about 200032000 tons of elemental Metal (Cr) annually escapes into the environment ${ }^{11}$. The other heavy metal which is a major concern in this study is
Nickel. Vesali-Naseh et al in 2012 had a research study on the Heavy metal concentrations and magnetic susceptibility of sediment samples which were analyzed as indicators of urban and industrial contamination in Anzali wetland in Gilan, Iran. They reported that the average value of Ni concentration was above SEL $(50 \mathrm{mg} / \mathrm{kg})$ at all cores. Concentration of Ni was higher than the values of other lakes and This fact could be related to the industrialization and urbanization of the wetland basin $^{12}$. Heavy metal contamination in aquatic ecosystems due to discharge of industrial effluents may pose a serious threat to human health. Alkaline precipitation, ion exchange columns, electrochemical removal, filtration, and membrane technologies are the currently available technologies for heavy metal removal ${ }^{13}$. The conventional technologies are not economical and may produce adverse impacts on aquatic ecosystems. Phytoremediation of metals is a costeffective "green" technology based on the use of specially selected metal-accumulating plants to remove toxic metals from soils and water. Plants are ideal agents for soil and water remediation because of their unique genetic, biochemical and physiological features ${ }^{14}$. Aquatic plant communities are good candidates for treating groundwater contamination in engineered systems because of the large surface area, ease of culture and high organic uptake potential ${ }^{15}$. The Co and $\mathrm{Cu}$ accumulators have been found in more than dozen families ${ }^{16-22}$. Based on the database, Akhani et al have recently demonstrated that the flora of the south Caspian Area included 3234 species belonging to 856 genera and 148 families of vascular plants which are known from the geographic boundaries of the three provinces Gilan, Mazandaran and Golestan and Talish in Azerbaijan Republic. Four genera and six species belong to basal angiosperms and intermediate between Eudicots and Monocots (Nymphaeaceae, Aristolochiaceae and Ceratophyllaceae ${ }^{23}$. As Iran is one of the richest countries in the world as regards genetic resources of medicinal plants that some of them are export ${ }^{24}$. We have studied on potential ability of Nymphaeaceae due to accumulate Chrome and Nickel as the major concern in wetland pollution. The Nymphaeaceae is a family of flowering plants. Members of this family are commonly called water lilies and live 
as rhizomatous aquatic herbs in temperate and tropical climates around the world. The family is further characterized by scattered vascular bundles in the stems, and frequent presence of latex, usually with distinct, stellatebranched sclereids projecting into the air canals. Hairs are simple, usually producing mucilage (slime). Leaves are alternate and spiral, opposite or occasionally whorled, simple, peltate or nearly so, entire to toothed or dissected, short to long Petiole (botanyiolate), with blade submerged, floating or emergent, with palmate to pinnate venation. Stipules are either present or absent. Flowers are solitary, bisexual, radial, with a long pedicel and usually floating or raised above the surface of the water, with girdling vascular bundles in receptacle ${ }^{25}$. In Iran few studies have been conducted to find more effective plants for phytoremediation of various pollutants. The objective of this research was investigation of the potential of the Nymphaeaceae high-biomass $\mathrm{Ni}$ hyperaccumulator to phytoextract $\mathrm{Cr}$ and $\mathrm{Ni}$ from artificial metalliferous media .

\section{MATERIALAND METHODS}

\section{Study of area}

The Anzali Wetland complex (372- $37^{\circ} 37$ $\mathrm{N}-49^{\circ} 35^{\prime} \mathrm{E}$ ), is situated on the southwest shore of the Caspian Sea north-east of Rasht and adjacent to Bandar-e-Anzali town on the northern boundary in Gilan province, northern $\operatorname{Iran}^{26-28}$. The Caspian Sea (Figure 1), which is located in the northern I. R. Iran, is the largest lake in the world and is connected to the distant Baltic through canals and the river Volga ${ }^{29}$.

Anzali wetland is located in Gilan Province. There are more than 80 rivers in the Province. The main rivers carrying both sanitary and industrial wastewater and entering to the wetland are about 11 major and 30 minor rivers. This will bring a sum up of about $71 \mathrm{~cm}^{3} / \mathrm{s}$ of polluted water. In other words, over six mil-lions cubic meter of polluted water will enter the wetland every day. These will enrich the nutrients as well as increases in the amount of the heavy metals of the wetland. According to the Jafari report in 2009 the pollution of the Province is increasing each year, which came to over 2,500,000 persons in 2009. More than half of the population lives in the two main cities of Rasht and Anzali Port. Municipal and trade wastewater of these cities discharged either indirectly from Pir-Bazar river or directly to the wetland. Not only the wastewater effluent from the houses and trade centers enter directly to the wetland, but also household garbage and solid waste from commercial places have chance to pollute the wetland. The high level of water in Rasht, no proper disposal of wastes and discharge of municipal and industrial (including sanitary wastewater) wastewater especially y food ones were the main factors for high amount of fecal and total coliforms in these rivers. It is obvious that in the rivers which agriculture runoff is discharged, the amount of these parameters is low.

\section{Plant culture and phytoremediation experimental design}

The phytoremediation experiment was conducted in spring and summer 2014. The Nymphaeaceae sample was collected from Anzali located in Miraj Nymphaeaceae was collected from area located in Anzali lagoon (Iran) where is full of Nymphaeaceae's ten days before the experiment. They were in sterile plastic bottle and were transported to laboratory. Plants were treated with different molarity of Chromium and Nickel solutions for 60 days. Then they were kept outdoors in an enclosed area except during extreme weather conditions. Cr was introduced independently at two speciation as $\mathrm{Cr}$ (III) and $\mathrm{Cr}$ (VI), which known for their diverse physicochemical properties and different influence on living organisms. Nutrient solution was supplied to the plants daily, starting one week after transplanting. The composition of the nutrient solution was $0.5 \mathrm{mM} \mathrm{Ca}\left(\mathrm{NO}_{3}\right)_{2}, 3.1 \mathrm{mM}$ $\mathrm{NH}_{4} \mathrm{NO}_{3}, 0.01 \mathrm{mM} \mathrm{KH}_{2} \mathrm{PO}_{4}, 50.0 \mu \mathrm{M} \mathrm{KCl}, 0.2 \mu \mathrm{M}$ $\mathrm{CuSO}_{4}, 2.0 \mu \mathrm{M} \mathrm{MnSO}_{4} \cdot \mathrm{H}_{2} \mathrm{O}, 0.5 \mu \mathrm{MZnSO}_{4} \cdot 7 \mathrm{H}_{2} \mathrm{O}$, and $0.2 \mathrm{mM} \mathrm{MgSO}_{4}$. The plant treatment groups were supplied with $100 \mathrm{ppm}$ (Ni T1), $200 \mathrm{ppm}$ ( Ni T2) and $300 \mathrm{ppm}$ (Ni T3) Nickel in the form of Ni $\left(\mathrm{NO}_{3}\right)$; and $100 \mathrm{ppm}(\mathrm{Cr}(\mathrm{VI}), \mathrm{T} 1)$,300 ppm (Cr(VI), $\mathrm{T} 2)$ and $600 \mathrm{ppm}(\mathrm{Cr}(\mathrm{VI}), \mathrm{T} 3)$ chromium in the form of $\mathrm{K}_{2} \mathrm{Cr}_{2} \mathrm{O}_{7}$ and the same concentration of $\mathrm{Cr}$ (III) too in the form of $\mathrm{CrCl}_{3}$. The plants were treated with metal solutions for 60 days and then were harvested after every 10 days.

\section{Chemical analysis}

The plants were cut about $1-2 \mathrm{~cm}$ as they could be controlled by cutting top growth in this study. The study on root and shoot of plant was 
done separately .The harvested parts were dried at $80^{\circ} \mathrm{C}$ in an oven for 24 hours. Dry parts were then ground and weighed. Plant samples (approximately $0.5 \mathrm{~g}$ ) were digested with concentrated $\mathrm{HNO}_{3}$ and $\mathrm{H}_{2} \mathrm{O}_{2}$ [5, 30-33]. The digested solution was filtered and then analyzed for Ni and $\mathrm{Cr}$ (III) and $\mathrm{Cr}$ (VI), concentration using inductively coupled plasma-atomic emission spectrometry (ICP-AES).

\section{Statistical method}

One-parametric Kruskal-Wallis/MannWhitney $U$ tests were applied to compare differences between objects. Non-parametric multiple comparison test (Dunn's test) was performed to determine statistical significance of results at $\alpha=0.05$. The GLM procedure was used for analysis of different metal treatments with means separated by Duncan's multiple range test at $p<0.05$. The CORR procedure was used for correlation analysis with means separated at $p<0.05$.

\section{RESULTS}

\section{Chemical analysis}

Metal accumulation in plant shoots and roots increased significantly with an increase in applied metal solution concentration in both Nickel (figure 2) and $\mathrm{Cr}(\mathrm{III})$ and $\mathrm{Cr}(\mathrm{VI})$, (figures 3 and 4 respectively ) treated groups. In figures 2, 3 and 4

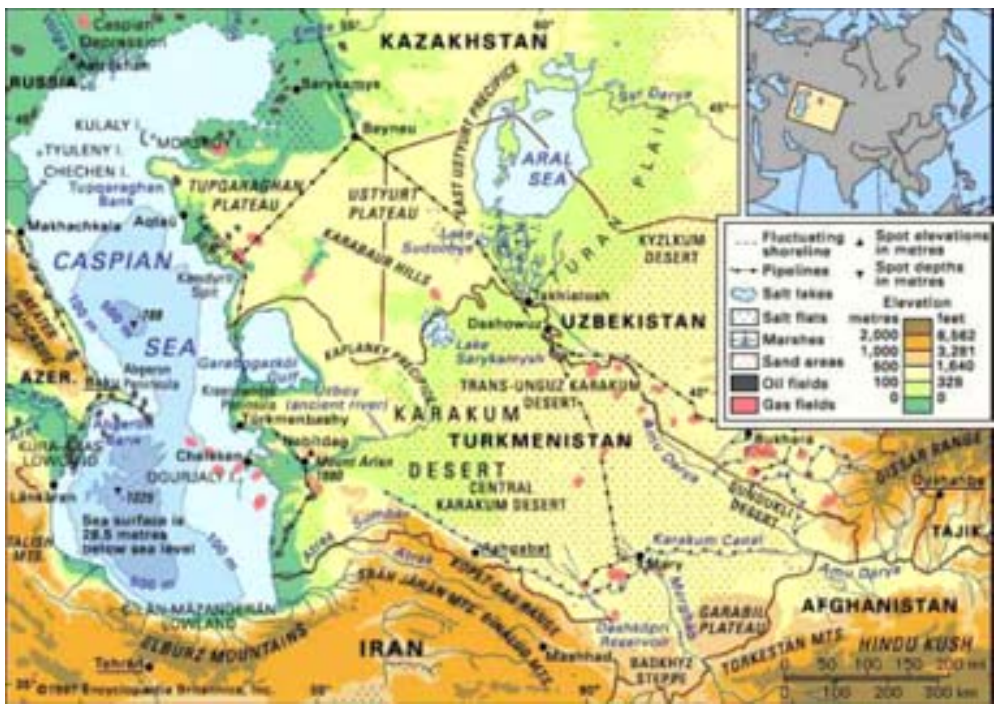

Fig. 1. Map of Caspian Sea and Anzali wetland

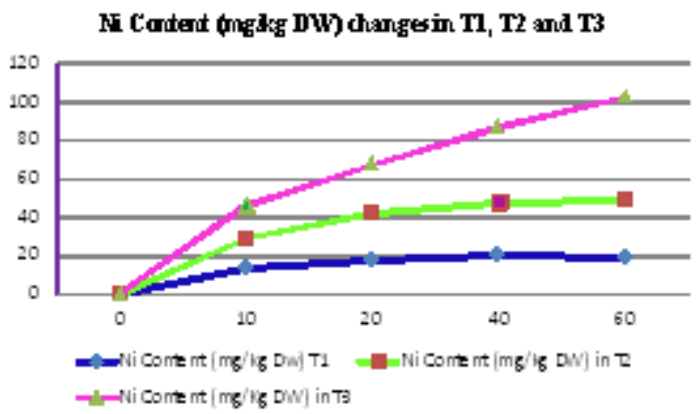

Fig. 2. The mean content of Nickel (mg/kg DW) in Nymphaeaceae treatment groups in contaminated 100 ppm (Ni T1) , 200 ppm ( Ni T2) and 300 ppm (Ni

T3) Nickel solution in the form of $\mathrm{Ni}\left(\mathrm{NO}_{3}\right)$.

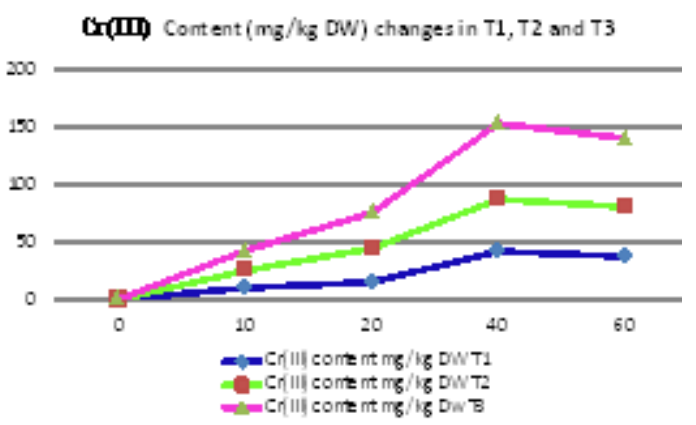

Fig. 3. The mean content of $\mathrm{Cr}(\mathrm{III})(\mathrm{mg} / \mathrm{kg} \mathrm{DW})$ in Nymphaeaceae treatment groups in contaminated 100 ppm (Cr(III), T1) ,300 ppm (Cr(III), T2) and 600 ppm ( $\mathrm{Cr}(\mathrm{III}))$, T3) chromium in the form of $\mathrm{CrCl}_{3}$ 
the mean contents of heavy metals are reported. The metal concentrations remained high in roots compared to shoots in Cr (III) and Cr (VI), treated groups, while metal content was higher in shoots than roots in $\mathrm{Ni}$-treated groups. The ratios of shoot/ root ratios were calculated to indicate the translocation efficiency of $\mathrm{Ni}$ and $\mathrm{Cr}$ from root to shoot. The Cr (III) concentrations in samples after 10, 20, 30 and 40 days are higher in plant than $\mathrm{Cr}(\mathrm{VI})$, hence the translocation factor ratios were less than one for Cr ( VI) treated plants. Even though the $\operatorname{Cr}(\mathrm{VI})$, concentration of shoots and roots of Cr treated plants in 50 and 60 days treated plants is higher compared to controls (T1,T2 and T3 Cr(III) ), the extent of metal accumulation and uptake efficiency of Cr(III) was lower than that of Cr(VI), in long term contaminated situation study. Most of plants in T3 group for Cr (VI) samples died after 60 days remaining in contaminated water.

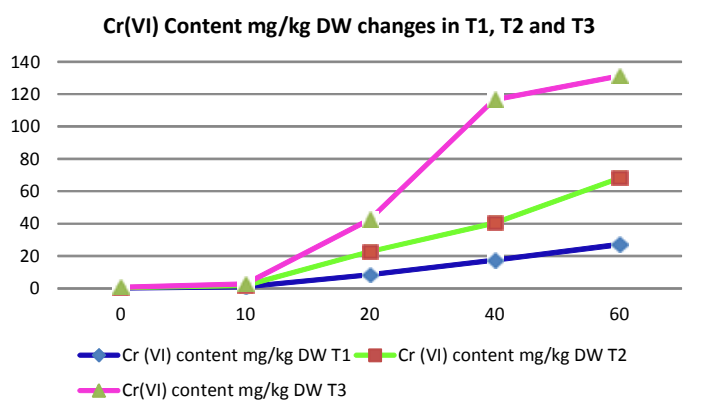

Fig. 4. The mean content of $\mathrm{Cr}(\mathrm{VI})(\mathrm{mg} / \mathrm{kg} \mathrm{DW})$ in Nymphaeaceae treatment groups in contaminated 100 ppm (Cr(VI), T1) ,300 ppm (T2) and 600 ppm (Cr(VI), T3) chromium in the form of $\mathrm{K}_{2} \mathrm{Cr}_{2} \mathrm{O}_{7}$

\section{DISCUSSION}

According to ATSDR, current evidences indicate that $\mathrm{Cr}(\mathrm{VI})$ is a cancer agent only by inhalation. Chronic inhalation studies on mice exposed to airborne $\mathrm{Cr}$ (VI) suggest that $\mathrm{Cr}(\mathrm{VI})$ is an animal carcinogen ${ }^{34}$. The mice developed lung tumors from exposure to $4.3 \mathrm{mg} / \mathrm{m} 3$ of $\mathrm{Cr}(\mathrm{VI})$.However, a number of chronic animal studies showed no carcinogenic effects in rats, rabbits, or guinea pigs exposed to $1.6 \mathrm{mg} / \mathrm{m} 3$ of $\mathrm{Cr}(\mathrm{VI})^{34-37}$. Thus, cancer effects on animals seem to depend on the type of animal. Eating small amounts of chromium (VI) is not harmful. However, eating or drinking large amounts in food or water can cause an upset stomach, ulcers, convulsions, and damage the kidneys and liver. This type of exposure can be fatal. There is not enough data to know if eating or drinking chromium (VI) causes cancer [38-39]. The results of this study revealed that Nymphaeaceae can accumulate high level of Chrome (VI) and (III) in a short time and their uptake rate by plant is significantly affected by their concentrations in the contaminated water $(\mathrm{p}<0.005)$.

The amount of Cr deposited in leaves in both Cr-treated plants differed significantly $(p<0.02)$. As expected the heavy metals uptake rate by this plant is significantly affected by number of plant cultivated as for Nickel uptake $(\mathrm{p}<0.03)$ while for chrome the $p$-value was less than 0.01 . The results of this research concluded that Nymphaeaceae in the contaminated water had suitable ability for phytoremediation by method and transmitting more Chrome and Nickel in $\mathrm{pH} \leq 7$ after 10 days of growth of Nymphaeaceae spices. Plant accumulation of all metals from single-element substrates indicate that the bioaccumulation coefficient increases as total metal concentrations increase. The present investigation revealed that water lilies could be great aquatic plant for phytoextraction of Chrome and Nickel from contaminated water. In fact, the highest efficiency of $\mathrm{Cr}$ accumulation by plant was occurred when the water was contaminated by $600 \mathrm{mg} / \mathrm{kg}$ of $\mathrm{Cr}$ (III) and also Cr (VI) . The Biomass factor values more than one, indicated that Nymphaeaceae is potentially useful for remedying heavy metal contaminated water and introduce as $\mathrm{Ni}$ and $\mathrm{Cr}$ hyperaccumulator plant. Also, this research suggests more investigations by other genera and families of vascular plants applying as aquatic plants for these heavy metals and other toxic metals such as Lead, cadmium, arsenic and Mercury.

\section{Conflict of Interest}

The authors have declared no conflict of interest.

\section{REFERENCES}

1. Nriagu , J.O. Global inventory of natural and anthropogenic emission of trace metals to the atmosphere. Nature, 1979; 279: 409-411.

2. Sayyed, M.R.G, Sayadi, M.H. Variations in the heavy metal accumulations within the surface soils from the Chitgar industrial area of Tehran. Proceedings of the International 
Academy of Ecology and Environmental Sciences, 2011; 1(1): 36-46.

3. Dadgar, S., Teimoori, B., Yousefi S., Tabatabaei, M. Determination of PCB levels in skin and muscle of northern pike (Esox lucius) in Anzali Wetland, Iran. Annals of Biological Research, 2014; 5(1):112-117. Available in site : http:// www.scholarsresearchlibrary.com

4. Saghali, M., Baqraf, R., NejatkhahManavi, P., Abbas Hosseini, S., Patymar, R. Assignment of Concentration of Heavy Metals (Cr, Zn, Cd, $\mathrm{Pb}$ ) In Sediments of Gorgan Bay and South East the Caspian Sea (Golestan Province- Iran)20102011. Environment and Ecology Research .2013; 1(2): 27-31. Available in Site: http:// www.hrpub.org/download/201309/ eer.2013.010201.pdf.

5. Ziarati, P., Alaedini, S. The Phytoremediation Technique for Cleaning up Contaminated Soil By Amaranthus sp. J. Environ. Anal. Toxicol. 2014; 4 :208. doi: 10.4172/2161-0525.1000208.

6. Seifi-Nigje Gheshlagh, F., Ziarati, P., Arbabi Bidgoli, S. Seasonal Fluctuation of Heavy Metal and Nitrate Pollution in ground water of Farmlands in Talesh Gilan,Iran. International Journal of Farming and Allied Sciences. 2013; 2(20): 836-841.

7. Ziarati, P.; Khoshhal, Z.; Asgarpanah, J.; Qomi, M. Intl. J.Farm. \& Alli. Sci., 2013; 2: 383-387. Available in Site: http://ijfas.com/wp-content/ uploads/2013/07/383-387.pdf.

8. Ayati, B. Investigation of Sanitary and Industrial Wastewater Effects on Anzali Reserved Wetland. Presented to MAB-UNESCO . 2003. Available in Site: http://www.unesco.org/mab/doc/mys/ 2002/ayati/ayati.pdf.

9. Tashayoie, H. R., Ghannadi, M., Elahi Nia, N., Boronz, A. R., Khalili, M. "Water and Wastewater Industry of Iran, Water and Wastewater Company” (Persain) 1999.

10. Industrial and Mineral Gilan State’s Guidebook "Industrial and Mines Organization in Gilan Province”, 2001.

11. Rizwana, M., Darshan ,M. Nilesh, D. Phytoremediation of Textile Waste Water Using Potential Wetland Plant: Eco Sustainable Approach. International Journal of Interdisciplinary and Multidisciplinary Studies (IJIMS), 2014; 1(4): 130-138. Available online at http://www.ijims.com .

12. Vesali Naseh, M. R., Karbassi, A., Ghazaban, F., Baghvand, A., Mohammadizadeh, M.J. Magnetic susceptibility as a proxy to heavy metal content in the sediments of Anzali wetland, Iran. Iranian Journal of Environmental Health Science \& Engineering . 2012; 9: 34. doi: 10.
1186/1735-2746-9-34.

13. Rai, P.K. Heavy metal pollution in aquatic ecosystems and its phytoremediation using wetland plants: an ecosustainable approach. Int. J. Phytoremediation, 2008; 10(2):131-58.

14. Ahmadi, M., Ziarati , P., Manshadi, M., Asgarpanah, J., Mousavi, Z. The Phytoremidiation Technique for Cleaning Up Contaminated Soil by Geranium (pelargonium roseum). International Journal of Farming and Allied Sciences. 2013; 2(15): 477-481.

15. Ziarati, P., Kheradmandi, S. The Potential of Nymphaeaceae as high-biomass Nickel and Chrome hyperaccumulator . Proceeding in $18^{\text {th }}$ Iranian Pharmacy , .journals.tbzmed.ac.ir/ PHARM/Document/18thIranianPharmacy/ 32.pdf.

16. Homer , F.A., Morrison, R.S., Brooks, R.R., Clemens, J., Reeves, R.D. Comparative studies of nickel, cobalt, and copper uptake by some nickel hyperaccumulators of the genus Alyssum. Plant Soil , 1991; 138: 195-205.

17. Keeling, S.M., Stewart, R.B., Anderson, C.W.N., Robinson, B.H. Nickel and cobalt phytoextraction by the hyperaccumulator Berkheya coddii: Implications for polymetallic phytomining and phytoremediation. Int $J$ Phytorem, 2003; 5:235-244.

18. Li, Y.M., Chaney, R.L., Brewer, E.P., Angle, J.S., Nelkin, J. Phytoextraction of nickel and cobalt by hyperaccumulator Alyssum species grown on nickel-contaminated soils. Environ Sci Technol , 2003; 37:1463-1468.

19. Ziarati, P., Ziarati ,N. N., Nazeri , S., SaberGermi, M. Orient. J. Chem. 2015, 31(1): 317326. Available from: http:// www.orientjchem.org/?p=7693.

20. Faucon, M.P., Shutcha, M.N., Meerts, P. Revisiting copper and cobalt concentrations in supposed hyperaccumulators from SC Africa: influence of washing and metal concentrations in soil. Plant Soil, 2007; 30:29-36.

21. Wang, H., Shan, X.Q., Wen, B., Zhang, S.Z., Wang, Z.J. Responses of antioxidative enzymes to accumulation of copper in a copper hyperaccumulator of Commoelina communis. Arch Environ Contam Toxicol, 2004; 47: 185192.

22. Wang, H.O., Zhong, G.R. Effect of organic ligands on accumulation of copper in hyperaccumulator and nonaccumulator Commelina communis. Biol Trace Elem Res, 2011; 1(43): 489-499.

23. Akhani, H., Djamali, M., Ghorbanalizadeh, Ramezani, E. plant biodiversity of hyrcanian relict forests, $\mathrm{n}$ iran: an overview of the flora, 
vegetation palaeoecology, and conservation. Pak. J. Bot., Special Issue (S.I. Ali Festschrift). 2010; 42: 231-258.

24. Yousefia, M., Olyaei Juybari, E., Yahyapor, M.K., Dehpour, A. A. , Hoseinzade, M. Brine Shrimp Lethality Activity of land and fresh water Medicinal Plants. Advances in Environmental Biology, 2012; 6(3): 1196-1199.

25. Phylogeny, Classification and Floral Evolution of Water Lilies (Nymphaeaceae; Nymphaeales): A Synthesis of Non-molecular, rbcL, matK, and $18 S$ rDNA Data, Donald H. Les, Edward L. Schneider, Donald J. Padgett, Pamela S. Soltis, Douglas E. Soltis and Michael Zanis, Systematic Botany, 1999; 24( 1): 28-46.

26. Tahershamsi, et al., Effects of Seasonal Climate Change on Chemical Oxygen Demand (COD) Concentration in the Anzali Wetland (Iran). 18th World IMACS / MODSIM Congress, Cairns, Australia 13-17 July 2009 . Available in Site: http://mssanz.org.au/modsim09 .

27. Hosseinzadeh, Y., Saghafian, B., Bakhtiary, A. Impact Assessment of Periodical Variation Discharges on Water Quality of Anzali Wetland. Switzerland Research Park Journal. 2013; 102( 4): 228-234.

28. http://medlem.spray.se/davidgorgan/ Caspiansea.html.

29. Jafari, N. Review Ecological integrity of wetland, their functions and sustainable use. Journal of Ecology and Natural Environment, 2009; 1(3): 045-054. Available in Site: http:// www.academicjournals.org/JENE.

30. Ziarati, P., Iranzad-Asl, S., Asgarpanah, J. Companion Pelargonium roseum and Rosmarinus officinalis in cleaning up contaminated soil by phytoextraction technique the role of companion plants in boosting phytoremediation potential. International Journal of Plant, Animal and Environmental Sciences. 2014; 4(3): 424-430. Available in Site: http://www.ijpaes.com/admin/php/uploads/ 648_pdf.pdf .

31. Balaji, B. Maruthi Sridhar, F., Han X., Diehl, V. S., Monts, D., L. ,Yi Su . Effect of Phytoaccumulation of Arsenic and Chromium on Structural and Ultrastructural Changes of Brake Fern (Pteris vittata). Braz. J. Plant Physiol. 2011; 23 (4). Campos dos Goytacazes . http://dx.doi.org/10.1590/.

32. Jackson, M.L. Soil chemical analysis., Prentice Hall, New Jersey, 1958.

33. Han, F.X. and Banin, A. Long-term transformations and redistribution of potentially toxic heavy metals in arid zone soils. I. under saturated conditions. Water Air Soil Pollut. 1997; 95: 399-423.

34. Agency for Toxic Substances and Disease Registry (ATSDR), 2000, Toxicological Profile for Chromium, U.S. Department of Health and Human Services, Public Health Service, ATSDR, September 2000.

35. Sridhar, B.B.M, Han, F.X, Diehl, S.V, Monts, D.L, Su, Y. Monitoring the effects of Arsenicand Chromium- accumulation in Chinese brake fern (Pteris vittata) using microscopy and near infrared spectral reflectance. Int. J. of Remote Sens , 2007b; 28: 1055-1067.

36. Sridhar, B.B.M., Han, F.X., Diehl, S.V., Monts, D.L., Su, Y .Effects of Zn and Cd accumulation on structural and physiological characteristics of barley plants. Braz. J. Plant Physiol, 2007a; 19: 15-22.

37. Guertin ,J. Toxicity and Health Effects of Chromium (All Oxidation States). L1608_C06. fm. 2004; Page 213. Available in site : http:// www.engr.uconn.edu/ baholmen/docs/ ENVE290W/National \% 20 Chromium \% 20Files\%20From\%20Luke/Cr(VI)\% 20 Handbook /L1608_C06.pdf .

38. http://www.eco-usa.net/toxics/chromium.shtml

39. Manshadi, M., Ziarati P, Ahmadi , M., Fekri, K. Greenhouse Study of Cadmium and Lead phytoextraction by five Pelargonium spices. Intl J Farm \& Alli Sci. 2013; 2(18): 665-669. Available in site :http://ijfas.com/wp-content/ uploads/2013/10/665-669.pdf.

40. Ziarati, P., Nazif, M., Khandehrouy, M. Decreasing bio-toxicity of fume particles produced in welding process by Aloe-Vera L. Oriental Journal of Chemistry. 2015; 31 (SPL Ed.1). 